\title{
Territorial Servitization: Exploring the virtuous circle connecting

\author{
knowledge-intensive services and new manufacturing businesses
}

\author{
Esteban Lafuente ${ }^{1}$ \\ Department of Management, Universitat Politècnica de Catalunya (Barcelona Tech) \\ EPSEB, Av. Gregorio Marañón, 44-50, E-08028 Barcelona, Spain \\ Phone: +34 93405 4476, Fax: +34 933348960 \\ Email: esteban.lafuente@upc.edu \\ Yancy Vaillant \\ ESC Rennes School of Business \\ 2 rue Robert d'Arbrissel CS 76522, 35065 Rennes Cedex, France \\ Email: yancy.vaillant@esc-rennes.fr \\ Ferran Vendrell-Herrero \\ Birmingham Business School, University of Birmingham \\ Edgbaston, B15 2TT, Birmingham, UK \\ Email: f.vendrell-herrero@bham.ac.uk
}

Please cite as: Lafuente, E., Vaillant, Y., Vendrell-Herrero, F. (2017). Territorial servitization: Exploring the virtuous circle connecting knowledge-intensive services and new manufacturing businesses. International Journal of Production Economics, in press. DOI:

http://dx.doi.org/10.1016/j.ijpe.2016.12.006

Acknowledgements: For their ideas and insights that helped us to improve the paper we are grateful to seminar participants at Birmingham Business School (Global Value Chain Seminar), Aston University (Servitization Conference 2015), and at the Universidad Rey Juan Carlos (4th International Conference on Business Servitization 2015). The authors are also thankful to Glenn Parry (UWE), Tommaso Aquilante (University of Birmingham) and the four anonymous referees for their insightful comments. Yancy Vaillant received financial support from the ESC Rennes School of Business. Esteban Lafuente acknowledges financial support from the Spanish Ministry of Science and Innovation (Grant: ECO2013-48496-C4-4-R). Ferran Vendrell-Herrero received financial support from the Spanish Ministry of Science and Innovation (Grant: ECO2014-58472-R) and from the European Union (Horizon 2020 Marie Skłodowska-Curie Actions Project MAKERS: Smart Manufacturing for EU Growth and Prosperity - Grant: 691192).

\footnotetext{
${ }^{1}$ Corresponding author
} 


\title{
Territorial Servitization: Exploring the virtuous circle connecting
}

\author{
knowledge-intensive services and new manufacturing businesses
}

\begin{abstract}
The mainstream servitization literature mostly describes the success of manufacturing firms in integrating services for their corporate clients. However, the literature is relatively silent on how territories capitalize on the potential interconnectedness between manufacturing firms and the knowledge-intensive business service (KIBS) sector. The analysis of the outcomes that result from the mutually dependent associations between manufacturing businesses and KIBS firms, a process that we call Territorial Servitization, is of great relevance for academics and policy makers. This research hypothesizes that there is a positive symbiotic and bidirectional link between the growth in KIBS activity and employment generation by manufacturing sector startups. Furthermore, we scrutinize the mediating role over this relation of relevant industry characteristics, in our case the stock of manufacturing firms and the total number of freights transported. The empirical application considers a unique dataset created from multiple sources - the Global Entrepreneurship Monitor (GEM), the Spanish Institute of Statistics and Eurostat - for the 17 Spanish regions during the period 2006-2012. The results support the view that territorial servitization contributes to employment creation in manufacturing sectors. Territories with a vigorous manufacturing base benefit from a virtuous circle in which KIBS start-ups and newly formed manufacturers are connected through the economic activity of incumbent manufacturing firms. The study offers valuable insights for scholars and policy makers on how to implement specific policies-e.g., the development of digital infrastructures - that facilitate the interaction between manufacturing and KIBS businesses, thus fuelling territorial development.
\end{abstract}

Keywords: Territorial servitization, KIBS, new manufacturing firms, industry configuration 


\section{Territorial Servitization: Exploring the virtuous circle connecting knowledge-intensive services and new manufacturing businesses}

\section{Introduction}

Over the last decade, the provision of knowledge-intensive services is widely recognized as one of the key engines for the consolidation of knowledge-based economies (European Commission, 2007, 2012). Manufacturing businesses have a growing demand for knowledge-based services (Cusumano et al., 2015). This is because their competitive position increasingly stems from their ability to introduce value-adding services into their operations, and to offer integrated packages of goods and services; that is, through servitization strategies (Vandermerwe \& Rada, 1989; Matthyssens \& Vandenbempt, 2008; Suarez et al., 2013).

Servitization is increasingly recognized as a source of value with important strategic and economic potential (Neely, 2008; Gunasekaran \& Ngai, 2012; Cusumano et al., 2015). Also, servitization can be seen as a mechanism to develop innovation capabilities and enhance customer engagement by realizing a shift from products to product-service systems (Visnjic \& Van Looy, 2013; Lee et al., 2016; Vendrell-Herrero et al., 2016).

Despite a growing stock of literature on the subject servitization research mostly adopts a micro-level approach, which leads to a dearth of work on how service-oriented business models contribute to territorial performance, and on how policy makers can encourage servitization processes in manufacturing industries (Bourlès et al., 2013). The territorial analysis of the relationship between the configuration of the local industrial fabric and increased provision of services remains empirically untested. This is the focus of this study.

The renaissance of local manufacturing sectors has been found to result in some cases from the presence of a dynamic knowledge intensive business services sector (KIBS) (Arnold et al., 2016; Kohtamäki and Partanen, 2016). The local presence of knowledge-intensive services has been shown to help new manufacturers internalize the value-adding capacity of services, 
while at the same time contribute to alleviating operational weaknesses linked to their liability of both newness and smallness (Grönroos \& Voima, 2013). Similarly, studies into Marshallian industrial districts have given much evidence of the presence of production processes that form at the meso-level from the interactions of different specialized professionals and SMEs to materialize a related production system (Becattini, 1990).

In our understanding these considerations invite the idea that servitization and the benefits of knowledge-intensive service provision do not necessarily have to be fully integrated within the manufacturer's internal value chain. There may be benefits to Territorial Servitization. Conceptually, territorial servitization surpasses organizational boundaries. It embodies the aggregate outcomes-e.g., economic, employment and other social outputs demanded by stakeholders — resulting from the various types of mutually dependent associations that manufacturing and knowledge-intensive service businesses create and/or develop within a focal territory. Territorial servitization can contribute to local competitiveness through the virtuous circle it helps stimulate. A resilient local manufacturing sector can potentially attract or stimulate the creation of complementary knowledge-intensive service activity firms, which in turn may facilitate the creation and growth of new manufacturers.

Therefore, this study extrapolates from the servitization literature (see e.g., Suarez et al., 2013; Cusumano et al., 2015) to propose that at a meso-level the value of territorial servitization produced through the dealings of local manufacturers and KIBS will be linked to greater competitiveness and employment generation by local manufacturers. More concretely, we evaluate the mutual relationship between the start-up rate of knowledge intensive service businesses and employment in new manufacturers. Additionally, our model assesses how key industry characteristics — stock of manufacturing firms and the total number of freights transported - mediate the relationship between KIBS businesses and employment in new manufacturers in both causal directions.

This study looks into the role of the provision of professional services and employment in new manufacturing businesses, answering the call made by Baines et al. (2016), Arnold et al. (2016), and Vendrell-Herrero and Wilson (2016) for more research on how service-oriented 
business models contribute to territorial performance through the provision of services to manufacturing businesses, and on how policy makers can contribute to encourage and/or enhance servitization processes.

The empirical analysis considers a unique dataset generated from multiple sources. First, data on the knowledge-based service orientation of territories and the employment created by new manufacturers at the regional level was obtained from the Global Entrepreneurship Monitor (GEM) databases for the period 2006-2012, which contains information for more than 176,000 observations. Second, data on the variables related to the territorial manufacturing activity - in our case measured by the stock of manufacturing firms and the total number of freights transported — were obtained from Eurostat databases. Third, macroeconomic figures were obtained from the Spanish Institute of Statistics. Data from the three sources allow the creation of a panel dataset including the 17 Spanish regions for the period 2006-2012.

The proposed approach offers a novel perspective that aims to better understand how policy makers can boost the relationships between new manufacturers and KIBS and the potential benefits resulting from this relationship, in terms of employment generation. The analysis of the territorial economic outcomes that flow from the virtuous circle connecting new manufacturers and KIBS contributes to identify what policy actions can help capitalize on the increased servitization activity that results from a greater consolidation of new manufacturers.

\section{Theoretical underpinning and hypotheses development}

\subsection{Servitization literature: Extending mainstream research}

In enhancing their competitive advantage manufacturers have shifted their focus from products to integrated solutions, containing both product and service offerings (Matthyssens \& Vandenbempt, 2008; Baines \& Lightfoot, 2014). Vandermerwe \& Rada (1989) dubbed this business model servitization, while Barnett et al. (2013) defined servitization as the process of seeking additional value through taking services propositions to the market. Recent figures indicate that, globally, more than a third of large manufacturing businesses offer services, while this rate increases to over $60 \%$ in western economies (Neely, 2008; Crozet \& Milet, 2015). 
The scholarly debate on servitization has focused on the driving forces of adopting servitization strategies (Vandermerwe \& Rada, 1989; Wise \& Baumgartner, 1999; Matthyssens \& Vandenbempt, 2008; Lee et al., 2016), on the implementation process of servitization (Oliva \& Kallenberg, 2003; Cook et al., 2006; Parry et al., 2012), and on the organizational benefits resulting from the adoption of servitization strategies (Neely, 2008; Visnjic \& Van Looy, 2013). The anticipated benefits of servitization approaches are well documented in the literature, including more stable revenues, higher growth rates and superior long-term profitability (Smith et al., 2014; Cusumano et al., 2015; Rabetino et al., 2015; Visnjic et al., 2016).

Nevertheless, most existing studies examine the servitization phenomenon from a microeconomic perspective. Although public administrations in the US and Europe acknowledge the potential transformative power of service innovation (European Commission, $2011 ; 2012)$, the analysis of the territorial impact of servitization processes based on meso or macro approaches remains largely unaddressed.

Rocha and Sternberg (2005) detected that the level of entrepreneurial activity in regions with geographically proximate groups of established interconnected firms and institutions contributed comparatively more towards regional economic performance. The key, according to these authors, does not come from economic territorial specialization or from the pure quantitative agglomeration of firms in a particular region, but rather from the interconnections and complementarities that link these together (Boix \& Vaillant, 2011). From this we can extrapolate that territorial servitization, as a production process linking services and industry, may enhance the local impact of manufacturing activity on regional competitiveness facilitating local knowledge diffusion.

It has long been observed that the internal economies of the manufacturing firm could be disaggregated across several interconnected specialized firms. Alfred Marshall (1890) documented in the late 19th century the existence of a form of organization of production based on the concentration of people and small and medium-sized firms specialized in different parts of a production process. In these territories, internal large scale economies are substituted by external economies related to the existence of linkages between knowledge intensive service 
activity firms and local manufacturers together with an informal system of knowledge diffusion. This territorial servitization process appears to be more compatible as regional industrial strategy than the mass production basis of extensive mono-productive manufacturing.

As a contemporary version of the industrial district which contributed to the resilience of certain manufacturing-based economies of past decades (Bellandi \& Sforzi 2004), local economic development using territorial servitization shares a stock of existing industrial talent with entrepreneurial activity in manufacturing and knowledge intensive services that are interwoven within the local value chain in a way which helps differentiate and add competitiveness to the local industrial fabric.

\subsection{Territorial servitization: The links between knowledge intensive services (KIBS) and new} manufacturing firms

It has been argued that the ability of manufacturing businesses to achieve a sustainable competitive advantage will depend on the presence of economies of scale in services, and economies of scope in products and services (Teece, 2010), while efficient complementarities between core products and additional services might generate benefits to customers by reducing procurement costs and information asymmetries (Visnjic \& Van Looy, 2013). These arguments suggest a double-sided relationship between manufacturers and services providers (Figure 1).

----- Insert Figure 1 about here -----

From the service providers' point of view, the achievement of an advantageous position in the market will depend on their capacity to provide value-creating services to manufacturers (Teece, 1980). Muller \& Zenker (2001) describe KIBS as service businesses providing knowledge-based and a high intellectual value-added services mostly to other small and medium sized manufacturing firms. KIBS' services are mostly related to R\&D, management consulting, or IT outsourcing (Strambach, 2001). 
The local spillover benefits of innovative entrepreneurship — e.g., knowledge-based services - are profound (Acs \& Audretsch, 1988; Acs \& Varga, 2004). According to the OECD (2006, p. 7), KIBS businesses are sources and carriers of knowledge that influence the performance of the territory's industrial fabric by providing valuable knowledge-based services to other organizations, fuelling job creation and territorial performance. Existing studies support that the promotion of knowledge-based firms has a fundamental role to play within territorial development strategies (Lafuente et al., 2010; Vaillant et al., 2012; Jacobs et al., 2016).

At the territorial level, Sternberg \& Arndt (2001) reported that the innovation behavior of European firms is positively related to the performance of regional economic structures. Additionally, Arauzo (2005) found that start-up rates are positively affected by the level of territorial economic activity. This may suggest that a consolidated manufacturing base not only generates economic activity, but also creates the conditions to attract KIBS entrepreneurs to these territories. Not only can the resilience of local manufacturing entice KIBS to a given territory but a renaissance of manufacturing where incumbent and new firms interact can contribute to the strong presence of KIBS in an economy.

Vigorous manufacturing sectors are characterized by agglomeration economies (Rocha \& Sternberg, 2005). Both the stock of manufacturing businesses and their economic activity produce a spillover effect, which has direct consequences on local business performance (Andersson \& Lööf, 2011). This creates the conditions that are ripe for entrepreneurial activity (Munnell, 1992), thus enhancing the local development of knowledge-based sectors (Lafuente et al., 2010; Arnold et al., 2016).

Taken together, these arguments and evidence suggest that policy makers can capitalize on the territory's industry structure to facilitate the consolidation of new manufacturing businesses, and create reliable market conditions that thrive on the successful development of knowledge-based services sectors. Therefore, we hypothesize:

H1: A consolidated manufacturing base - in terms of stock of businesses and their economic activity - positively mediates the relationship from sustainable new manufacturing businessesin terms of employment-to the creation of knowledge-intensive business service firms. 
We now turn our attention to the relationship between KIBS businesses and the consolidation of new manufacturing businesses. From a manufacturing business' perspective, service inputs might affect performance in various ways. First, the entry of service providers might lead to develop new and more sophisticated services which can contribute to enhance performance, such as cash flow management tools for manufacturers or digital value-added services in telecommunication sectors. Also, availability of advanced services might increase operational productivity of both new and incumbent manufacturing businesses by, for instance, improving product delivery management systems or bidding tools for suppliers. Second, the adoption of servitization strategies provides manufacturers with better information about customers' needs, which is critical to future product development strategies (Visnjic \& Van Looy, 2013). Third, territories can capitalize on the potential spillovers resulting from strong knowledge-intensive service sectors, which can be observed in terms of increased competition in the provision of services (Bourlès et al., 2013). This way, enhanced KIBS sectors contribute to reduce services' costs, thus creating innovation incentives that facilitate the adoption of servitization strategies by new manufacturing firms (Zhen, 2012; Arnold et al., 2016).

Fourth, although Bowen et al. (1989) points to a cultural bias against service-specific values (e.g., heterogeneity and flexibility) because they contradict traditional manufacturing practices such as standardization and efficiency, professional services' reliability may enhance in territories where manufacturing sectors concentrate an important weight of economic activity. Arguably, the demand of knowledge-based services in territories with strong manufacturing sectors will be greater. This creates the conditions to develop service sectors, which translates in benefits for manufacturers in that the implementation of value-adding services help to reduce both operational disruptions and operational costs (Rabetino et al., 2015; Arnold et al., 2016).

In this context, we argue that new manufacturing businesses—exposed to liabilities of smallness and newness (Aldrich \& Auster, 1986) — have strong incentives to adopt serviceoriented strategies through the acquisition of knowledge-based resources from KIBS businesses; and that this is especially so in territories with both a strong manufacturing base and a 
competitive KIBS' sector. Existing evidence supports that KIBS businesses contribute to sustaining the competitive advantage of small and medium manufacturing firms. For instance, in their analysis of 804 manufacturing establishments in Canada, Doloreux \& Shearmur (2013) found that improvements in innovation-oriented outcomes follow the adoption of collaborations with KIBS. Also, the nature of professional services affects location decisions of KIBS entrepreneurs. Research reports that geographic proximity is not a necessary condition in building and maintaining a KIBS-manufacturing relationship and this might explain why KIBS often locate in rural areas (Lafuente et al., 2010; Shearmur \& Doloreux, 2015).

Servitization can be seen as a response of manufacturers to market pressures, and previous studies show that increased provision of advanced services positively impact both organizational performance metrics linked to revenues and employment (Gebauer \& Fleisch, 2007), and the economic restructuring of territories through the implementation of advanced technological capabilities (Baines \& Shi, 2015). This logic and evidence suggests the following relationship between knowledge-intensive services and manufacturers' performance:

H2a: A positive relationship exists between the creation of knowledge-intensive business service firms and the sustainability—in terms of employment—of new manufacturing businesses. H2b: A vigorous manufacturing base —in terms of stock of businesses and their economic activity - positively mediates the relationship from the creation of knowledge-intensive business service firms to the sustainability—in terms of employment—of new manufacturing businesses.

\section{Data and method}

\subsection{Sample}

The accurate analysis of whether there is a mutually dependent and systematic link between knowledge-based services sectors and the performance of new manufacturing firms requires three types of information: a measure of formation rates in KIBS businesses, a performance measure for new manufacturing firms, and information on the linkages between the analyzed sectors of the economy. 
The data used in this study come from multiple sources. First, information on both the knowledge-intensive orientation of the territorial entrepreneurial activity and the average employment created in new manufacturing firms at the regional level is obtained from the Adult Population Survey of the Spanish Global Entrepreneurship Monitor (GEM) for the period 20062012. The GEM project began in 1998 as a joint initiative of the London Business School and the Babson College to create an international entrepreneurship research network. Today, more than 70 countries take part in this research initiative, making the GEM project a world reference in the entrepreneurship field and a highly valued source of information for academics and policymakers in each of the participating countries. A comprehensive description of the GEM project and its methodology is presented in Reynolds et al. (2005).

In the case of Spain, the survey was conducted in each of the Spain's 17 Autonomous Communities by a leading professional market investigation and public opinion service firm selected and monitored directly by the International GEM Consortium. The sample was built based on a multiple stage sampling method using the Bellview Fusion computer-assisted telephone interview system. In the first stage, a random selection of municipalities was collected according to population quotas. In the second stage, telephone numbers corresponding to the different municipalities were randomly obtained from the annually updated 'España Office v5.2' database of fixed and mobile telephones. Finally, individuals aged between 18 and 65 inclusive were randomly selected by the mentioned software. The final sample used to reach the aim of this study contains 176,609 Spanish observations collected between 2006 and 2012.

Second, macroeconomic figures - unemployment and Gross Domestic Product (GDP) per head expressed at constant 2012 prices - were obtained from the Spanish Institute of Statistics. Third, data on the variables related to the configuration of the industry—stock of manufacturing firms and total number of freights transported by air, road and maritime meanswere obtained from the Eurostat databases.

In this study, the unit of analysis is the geographical region, so data from the three information sources was grouped to build a panel dataset including the 17 Spanish regions (NUTS-2) for the period 2006-2012, which totals 119 region-year observations. 


\subsection{Convening knowledge-intensive business services (KIBS)}

Knowledge-intensive service activities as increasingly recognized as one of the main engines for the consolidation of knowledge-based economies (European Commission, 2007). The demand of knowledge-based services is increasing with the efforts of European economies to enhance their competitive position, and this is especially evident in manufacturing sectors which have strong incentives to involve external agents (KIBS) to introduce value-adding services into their operations (Cusumano et al., 2015). The market and economic relevance of knowledge-intensive service businesses translates into increased academic research (see e.g., Rocha \& Sternberg, 2005; Lafuente et al., 2010; Arnold et al., 2016; Jacobs et al., 2016), and these two elements have led many European governing bodies to turn their attention to the development of a healthy KIBS sector (Europe INNOVA, 2009; European Commission, 2012).

Knowledge-intensive services businesses are innovation bridges that interplay with other economic agents acting as purchaser, provider or partner (Czarnitzki \& Spielkman, 2003), thus implying an in-depth interaction between the service provider and the end user (Cusumano et al., 2015; Kohtamäki and Partanen, 2016). One example of services provided by KIBS is the management of large samples of digital information, namely big data. Opresnik \& Taisch (2015) show that this service adds significant value to manufacturers' offering especially in B2B relationships by providing customers with tools that can be used to enhance cost saving policies and develop more informed strategic decision-making processes.

KIBS businesses show a distinctive way to access, create and integrate knowledge in their processes (Lafuente et al., 2010; Jacobs et al., 2016). According to the European Commission (2011), KIBS encompasses a wide range of activities including activities related to computing and information and communication technologies (NACE Rev-2: 62), architectural and engineering technical services (NACE Rev-2: 71), research and development (NACE Rev2: 72), as well as organizational-oriented services (NACE Rev-2: 69, 70, 73 and 78) -i.e., legal and accounting and auditing services, management consultancy, advertising and market research—and other knowledge-oriented services (NACE Rev-2: 74). 
The final sample drawn from the GEM databases comprises information for 1,463 KIBS created in Spain between 2006 and 2012, which represents 19.51\% of the total number of new businesses created in the previous 18 months included in the sample during the same period.

Looking at the types of advanced services provided by the sampled KIBS, we note that new businesses in computer and related activities - hardware and software consultancy, data processing, data management, maintenance of computing machinery-represent $12.58 \%$ of the new KIBS, while $3.35 \%$ of new KIBS fall into the research and development category. Finally, the majority of new KIBS operate in business-oriented services (84.07\%), including: auditing and legal consultancy, market research and business and management consultancy (56.12\%); architectural and engineering activities and related technical consultancy (15.24\%); technical testing and analysis (4.78\%); and advertising, packaging and IT security services (7.93\%).

At this point, it should be noted the diversity in the knowledge-intensive services and the economic potential and opportunities these firms offer to their corporate customers. In the context of our study, the presence of a variety of knowledge-based services suggests that manufacturing sectors might enhance their competitive position by developing specific capabilities to offer packages of goods and services, that is, through servitization processes.

\subsection{Variable definition}

Dependent variables. This study focuses on the relationship between new KIBS businesses and the employment created by new manufacturing firms in Spain. The regional rate of new KIBS business is measured as the proportion of new businesses (with less than 18 months of market experience) created in knowledge-intensive services sectors in any given period in each of the 17 Spanish regions. The second dependent variable captures a relevant contribution of new businesses to territorial performance, namely employment generation (Mueller et al., 2008; Eriksson et al., 2014). In this study, job creation is measured by the average number of employees of new manufacturing firms created in the previous 18 months. ${ }^{2}$

\footnotetext{
${ }^{2}$ The timing of the GEM annual population survey allows at distinguishing between businesses created in the same year of the survey (business with less than 6 months of market experience) and businesses
} 
Figure 2 breaks the 17 Spanish regions into high-KIBS versus low-KIBS regions, and compares the average employment created by new manufacturing businesses from 2006 to 2012 .

----- Insert Figure 2 about here -----

The figure shows not only the dramatic increase in the employment created by new manufacturers in regions with high rates of KIBS start-ups after 2008, but also the pronounced difference when compared to the pattern reported for regions with low rates of creation of KIBS businesses, a pattern that, as indicated in sections 1 and 2, has not received much attention.

Industry characteristics. The key independent variables used in this study seek to capture the impact that the configuration of the industry and industry intensity have on both the development of KIBS sectors and the employment level of new manufacturing firms at the regional level. On the one hand, we introduce the stock of manufacturing firms as a measure of the economic capacity of manufacturing sectors at the territorial level (Leydesdorff et al., 2006). On the other hand, the dynamics of the regional industrial fabric is measured by the total air and maritime transport of freights. This variable - a proxy for the level of activity or 'busyness' of firms in the territory - is expressed in thousands of tons of goods transported in and out of the region. ${ }^{3}$ These variables are lagged to avoid collinearity problems linked to reverse causality.

----- Insert Table 1 about here -----

Control variables. We control for time and for two variables commonly used to explain regional variations in business formation rates, that is, unemployment rates and market growth

created in the year prior to the survey. In our sample, the total new businesses formation rate (for businesses created in the previous 18 months) is $4.25 \%$.

${ }^{3}$ Eurostat data on freight transport at NUTS-2 level include air and maritime transport means. Road freight transport statistics are available at country level, while regional data (NUTS-2 level) on rail freight transport are collected every five years by Eurostat (http://ec.europa.eu/eurostat/statisticsexplained/index.php/Freight_transport_statistics\#Road_freight_2). Thus, and for consistency purposes, we employ the proposed variable (air and maritime freight transport) in our meso-level analysis. Keep in mind that 48 airports are spread across the 17 Spanish regions (http://www.aenaaeropuertos.es/en/passengers/airports-network.html), which further corroborate the appropriateness of the selected variable to proxy the level of economic 'busyness' of regions at the NUTS-2 level. 
(see e.g., Armington \& Acs, 2002; Acs et al., 2007; Reynolds et al., 2007; Eriksson et al., 2014).

The regional unemployment rate is expressed as the proportion of the economically active population without a job, while the regional Gross Domestic Product per head is expressed in 2012 constant euro, and is deflated with respect to inflation. Finally, we introduced a set of time dummy variables to rule out the potential effects of time trends.

\subsection{Method}

In line with the arguments that underpin this study, we argue that there is a mutual relationship between the creation of KIBS businesses and the employment created by new manufacturing businesses, and that these relationships are mediated by the size and intensity of the local industrial fabric. The hypotheses of this study were tested using the proposal by Surroca et al. (2010). This method, which extends the approach by Baron \& Kenny (1986), consists of the implementation of a two-stage modeling strategy that permits to accurately analyze mediation effects between the variables of interest.

In the first step, we compute instrumental variables for the rate of new KIBS businesses and employment created by new manufacturing firms by regressing each variable on the configuration of the industry and the control variables. These coefficients allow at estimating the residual of each variable by subtracting the predicted effect of the variables related to the configuration of the industry from the two dependent variables. These models are estimated by fixed-effects models and they have the following form:

$$
\begin{aligned}
& \mathrm{KIBS}_{i t}=\alpha_{0}+\beta_{1} \text { Stock of manufacturing firms }_{i t}+\beta_{2} \text { Freights transported }_{i t} \\
& +\beta_{3}{\text { Mean } \mathrm{KIBS}_{i t}+\beta_{4} \text { Control variables }}_{i t}+T_{t}+\eta_{i}+\varepsilon_{i t}
\end{aligned}
$$

$$
\begin{aligned}
\text { Employment }_{i t} & =\alpha_{0}+\beta_{1} \text { Stock of manufacturing firms }_{i t}+\beta_{2} \text { Freights transported }_{i t} \\
& +\beta_{3} \text { Mean employment }_{i t}+\beta_{4} \text { Control variables }_{i t}+T_{t}+\eta_{i}+\varepsilon_{i t}
\end{aligned}
$$

In equations (1a) and (1b) $\alpha_{0}$ is the constant term, $\beta_{j}$ are parameter estimates for the $j$ th independent variable, $\eta$ is the time-invariant fixed effect that controls for unobserved 
heterogeneity across regions $(i)$, and $\varepsilon$ is the normally distributed error term that varies crossregions and cross-time. Control variables include the unemployment rate and the GDP per head, while $T$ is a set of time dummies. Additionally, and for each period, we introduce the average value of the dependent variable in the model to account for potential regional peer effects (Angrist, 2014). In models like ours estimated through fixed-effects regressions the inclusion of peer effects is especially appealing as this variable allows at controlling for regional-specific effects that otherwise cannot be included in the model specification given that territory dummies are time-invariant. This variable is the average value of each dependent variable (KIBS business formation rate and employment created by new manufacturers), and is calculated for each period and each region following the NUTS-2 classification excluding the focal territory.

Based on the estimation results from (1a) and (1b) we compute the key instruments of our model. The instruments are obtained by subtracting the predicted effect of the configuration of the industry from the observed value of each dependent variable (the rate of new KIBS firms and employment created in manufacturing firms):

$$
\begin{aligned}
& \begin{aligned}
\mathrm{KIBS}_{i t}^{\text {INSTR }}=\mathrm{KIBS}_{i t}-\left(\beta_{1} \text { Stock of manufacturing firms }_{i t}\right) \\
-\left(\beta_{2} \text { Freights transported }_{i t}\right)
\end{aligned} \\
& \text { Employment }_{i t}^{\text {INSTR }}=\text { Employment }_{i t}-\left(\beta_{1} \text { Stock of manufacturing firms }_{i t}\right) \\
& -\left(\beta_{2} \text { Freights transported }_{i t}\right)
\end{aligned}
$$

The second step of the procedure allows at testing the mediating role of the configuration of the industry on the impact of the inflow of KIBS firms into the economy over the employment created by new manufacturing firms. To do this so, we estimate the full models introducing the instruments obtained in the first step $\left(\operatorname{KIBS}_{i t}^{I N S T R}\right.$ and Employment ${ }_{i t}^{I N S T R}$ ), along with the mediating industry-related variables and the control variables.

All specifications are estimated by fixed-effects regression models. This modeling strategy helps overcome collinearity and endogeneity problems. By construction, the correlation 
between the estimated instruments and the mediating industry variables is $1 \mathrm{low}^{4}$, and this prevents multicollinearity problems in model estimation (Wooldridge, 2008). The use of fixedeffects models controls for the potential endogeneity problems emerging from the correlation between the set of independent variables and the time-invariant region-specific unobserved heterogeneity. Also, all the variables used in the model specifications (instruments, industryrelated and control variables) are introduced as lagged terms $(t-1)$ to avoid potential endogeneity problems linked to reverse causality ${ }^{5}$. To test the proposed mediation hypotheses we run two model specifications. The first model evaluates the different relationships between the regional rate of KIBS business formation and employment in new manufacturing firms:

$$
\begin{aligned}
& \text { KIBS }_{i t}=\alpha_{0}+\gamma_{1} \text { Employment }_{i t-1}+\gamma_{2} \text { Control variables }_{i t-1}+T_{t}+\eta_{i}+\varepsilon_{i t} \\
& \text { Employment }_{i t}=\alpha_{0}+\gamma_{1} \text { KIBS }_{i t-1}+\gamma_{2} \text { Control variables }_{i t-1}+T_{t}+\eta_{i}+\varepsilon_{i t}
\end{aligned}
$$

The second set of model specifications evaluate the mediation of the industry configuration variables in the relationship between the KIBS' regional business creation rate and employment generated by new manufacturing firms. These models have the form:

$$
\begin{aligned}
& \text { KIBS }_{i t}=\alpha_{0}+\delta_{1} \text { Employment }_{i t-1}^{\text {INSTR }}+\delta_{2} \text { Stock of manufacturing firms }{ }_{i t-1} \\
& +\delta_{3} \text { Freights transported }_{i t-1}+\delta_{4} \text { Control variables }_{i t-1}+T_{t}+\eta_{i}+\varepsilon_{i t} \\
& \text { Employment }_{i t}=\alpha_{0}+\delta_{1} \mathrm{KIBS}_{i t-1}^{I N S T R}+\delta_{2} \text { Stock of manufacturing firms }_{i t-1} \\
& +\delta_{3} \text { Freights transported }_{i t-1}+\delta_{4} \text { Control variables }_{i t-1}+T_{t}+\eta_{i}+\varepsilon_{i t}
\end{aligned}
$$

In terms of our hypotheses, note that three conditions must hold to corroborate that the configuration of the industry mediates the relationship between the employment created by new

\footnotetext{
${ }^{4}$ The correlation between the estimated residual for the rate of new KIBS, the stock of manufacturing firms and the total number of freights transported is $0.1975(p<0.01)$ and $0.0877(p<0.05)$, respectively. The estimated residual for the employment created by new manufacturers is correlated with the stock of manufacturing firms $(0.1737, p<0.05)$ and uncorrelated with the total number of freights transported by air, road and maritime means $(0.1158, p>0.10)$.

${ }^{5}$ In our case, the robustness of the results is confirmed by the low or null correlation between the instruments and the dependent variables (Wooldridge, 2008). More concretely, the estimated instrument for the rate of new KIBS is correlated with the observed rate of new KIBS $(0.2862, p<0.01)$ and is uncorrelated with the employment created by new manufacturers $(0.1457, p>0.10)$. Similarly, the instrument for the employment created by new manufacturing firms is correlated with its corresponding observed variable $(0.6372, p<0.01)$ and is uncorrelated with the rate of KIBS formation $(0.2056, p>0.10)$.
} 
manufacturing firms and the creation of KIBS businesses (H1): 1) the rate of new KIBS impacts the industry configuration variables, 2) the employment in new manufacturing firms explains the rate of new KIBS ( $\gamma_{1}>0$ in equation (3a)), and 3) the instrument for the employment in new manufacturing businesses turns not significant in equation $(4 a)\left(\delta_{1}=0\right)$, while the industry intensity variables impact the rate of new $\operatorname{KIBS}\left(\delta_{2}>0, \delta_{3}>0\right.$ in equation (4a)).

Hypothesis $2 \mathrm{a}$ will be confirmed if the coefficient for the variable linked to the creation of KIBS businesses in equation (3a) is statistically significant $\left(\gamma_{1}>0\right)$. In the case of the KIBS-employment relationship expressed in equations (3b) and (4b) (hypothesis $2 b$ ), mediation will be corroborated if: 1) the rate of new KIBS impacts the industry configuration variables, 2) the rate of new KIBS explains employment in new manufacturing firms $\left(\gamma_{1}>0\right.$ in equation (3b)), and 3) the instrument for the rate of new KIBS turns not significant in equation (4b) $\left(\delta_{1}=0\right)$, while the variables related to the industry intensity impact the employment created by new manufacturing firms $\left(\delta_{2}>0, \delta_{3}>0\right.$ in equation (4b)).

\section{Empirical results}

This section presents the results of the empirical analysis. To address the threat of collinearity, we computed the average variance inflation factor (VIF) for all variables. In all model specifications presented in Table 3, the average VIF values are below the commonly used cut-off threshold of ten. The results for this diagnostic test do not raise collinearity concerns.

Concerning the fixed-effects model estimating the relationship between new KIBS businesses and employment in new manufacturing businesses, results in model 1 of Table 2 show that the subsequent employment level reported by new manufacturing businesses is significantly higher in territories with greater formation rates of KIBS businesses $\left(\gamma_{1}=0.0495\right.$ and $p$-value $<0.05)$. Additionally, results in model 2 indicate that the mediation effect of the analyzed industry variables — stock of manufacturing businesses and industry intensity —is weak. More concretely, the coefficient for employment of new manufacturers turns not 
significant and the parameter linked to the freights transported is the only industry variable that positively impacts the rate of new KIBS $\left(\delta_{3}=0.1913\right.$ and $p$-value $\left.<0.001\right) .{ }^{6}$ These results give partial support to our first hypothesis that states that a more consolidated manufacturing basein terms of stock of businesses and their economic activity—positively mediates the relationship from sustainable new manufacturing businesses — in terms of employment - to the creation of knowledge-intensive business service firms.

\section{----- Insert Table 2 about here -----}

Hypothesis 2a proposes a positive relationship between the KIBS business formation rate and the employment generated by new manufacturing businesses. This hypothesis is supported. The results in model 3 of Table 2 show that the coefficient for the lagged rate of new KIBS businesses is positive and statistically significant $\left(\gamma_{1}=0.3613\right.$ and $p$-value $\left.<0.05\right)$.

This result gives support to our argument that increased competition in knowledgebased service sectors creates incentives to reduce services' costs, which translates in higher levels of consumption of these services. Similar to Arnold et al. (2016), this finding suggests that a competitive KIBS sector-e.g., in terms of the cost of services-provides a fertile ground for new manufacturing businesses to introduce knowledge-intensive services in their value chain that contribute to their expansion. For example, new manufacturing businesses might demand knowledge-based services to enhance their market sustainability through the creation of better information systems about customers' needs, which is vital for product development strategies (Visnjic \& Van Looy, 2013; Cusumano et al., 2015).

Hypothesis $2 \mathrm{~b}$ proposes that territorial industry characteristics - in terms of stock of businesses and their economic activity—positively mediate the relationship from the creation of

\footnotetext{
${ }^{6}$ Note that a positive relationship between the rate of new KIBS businesses and the industry configuration variables is the third condition that must hold to corroborate that the industry configuration mediates the relationship between the employment created by new manufacturers and the rate of new KIBS businesses. Results in Table A2 of the Appendix confirm that the rate of new KIBS has a significant positive impact on the industry configuration variables (stock of manufacturing firms and freights transported).
} 
KIBS businesses to the sustainability—in terms of employment—of new manufacturing businesses. Results in models 3 and 4 of Table 2 confirm this hypothesis. As we previously indicated, KIBS formation rates positively impact the employment created by new manufacturing businesses (model 3). When the analyzed industry variables are included in the regression equation this relationship turns not significant, while the coefficients for both the stock of manufacturing businesses $\left(\delta_{2}=1.6773\right.$ and $\left.p<0.05\right)$ and the total freights transported $\left(\delta_{3}=0.1825\right.$ and $\left.p<0.05\right)$ positively impact employment of new manufacturers (model 4).

Overall, the findings support the mediation of industry characteristics: when these variables are included in the estimations, the relationships between KIBS formation rates and employment in new manufacturing businesses are no longer significant (models 2 and 4 in Table 2). These results point to the presence of a virtuous circle in which new KIBS and the employment created by new manufacturers are connected through industry factors related to size (stock of manufacturing businesses) and intensity (total freights transported).

\section{Discussion, implications and concluding remarks}

In this study, we propose that servitization and the benefits of the knowledge-intensive services provision can also be developed at the meso level by scrutinizing the relationship between knowledge-intensive business service (KIBS) sectors and employment in new manufacturing businesses. At the meso-level, we argue that 'Territorial Servitization' can contribute to local competitiveness and employment creation through the virtuous cycle generated when a resilient local manufacturing base attracts or stimulates the creation of complimentary KIBS businesses, which in turn facilitates the creation of new manufacturers.

More concretely, we hypothesized that industry characteristics related to industry sizemeasured by the stock of manufacturing firms — and industry intensity—-measured by the total freights transported in and out the territory - are critical to mediate the connections between new KIBS businesses and new manufacturers that seek enhanced competitiveness. Also, our analysis answers the call for further work on how service-oriented business models contribute to 
territorial performance, and on how policy makers can encourage and/or enhance servitization processes in manufacturing industries (Arnold et al., 2016; Vendrell-Herrero and Wilson, 2016).

The results reveal the existence of a beneficial 'Territorial Servitization' effect over regional competitiveness and local manufacturing industry employment creation. At the territorial level, a mutually dependent relationship exists between new KIBS businesses and new manufacturing businesses. Additionally, the findings support the argument that factors associated with the local industrial fabric - in our case, industry size and industry economic intensity - mediate the positive relationships between KIBS formation rates and the employment generated by new manufacturing businesses.

In the context of this study, we interpret the results in terms of territorial servitization where the renaissance of local manufacturing is stimulated by a virtuous circle in which the development of a solid KIBS sector and a sustainable system of new manufacturers forms more successfully in territories with an existing base of resilient manufacturers.

This paper has implications for how policy makers can effectively match support policies targeting the development of the local industry with market solutions generated by enhanced connections between new KIBS businesses and new manufacturing businesses. As any reinforcing loop, the system can be positive and virtuous but can also be negative in nature and lead to a vicious cycle. And although our study does not address the way to reverse the dynamics of an undesirable cycle, it does give indications as to how and when policy in certain cases may need to ignite the dynamics setting off the reinforcing loop or push them beyond the inflection point that will get the virtuous cycle to take hold. Much like the contribution of industrial districts and manufacturing clusters of past decades, the renaissance of manufacturing at a territorial level within a contemporary knowledge-based context now appears to require the symbiotic development of knowledge-intensive service provision and a flourishing of new manufacturing ventures in territories whose industry conditions - in terms of size and intensity — offer a favorable seedbed for territorial servitization to occur.

We show that territories do not materialize the generally positive effects of a solid KIBS sector and a strong manufacturing industry at the same intensity. Knowledge-based service 
businesses are both sources and carriers of knowledge that might impact territorial performance by providing high value-adding services to other organizations, fuelling job creation. We suggest that, to develop a strong KIBS sector, policy makers need to turn their attention to the characteristics of the territory's manufacturing industry and adopt support actions-e.g., the development of digital infrastructures (broadband or cell phone towers) - that enhance both connectivity and the interactions between manufacturing and KIBS firms across the territory.

Additionally, promoting knowledge-intensive businesses has a fundamental role to play within territorial development strategies (European Commission, 2012; Macneill \& Jeannerat, 2016). But, policy priorities should not focus on subsidizing knowledge-based entrepreneurial activities. On contrary, any attempt to develop a sustainable KIBS sector should be coupled with enhanced networking opportunities at the territorial level. This way, manufacturing businesses would be in a better position to exploit knowledge-intensive services, while territorial connectivity networks allow KIBS businesses to better reach all manufacturing businesses - regardless of their location — via the development and the provision of valueadding services (Arnold et al., 2016).

It must, however, be mentioned a series of limitations to the present study that, in turn, represent avenues for future research. First, like other studies on servitization, data do not permit the direct analysis of the underlying relationships between KIBS and manufacturing businesses. We do not evaluate how manufacturing organizations internalize professional services into their operations, nor do we assess the processes through which problem-driven efforts impact employment in these businesses. Further research on this issue would be valuable. For example, future studies should evaluate the depth in the connections between KIBS and new manufacturing businesses, and determine whether KIBS collaborate with one or several manufacturing businesses in areas with different levels of strategic relevance.

Second, future studies should corroborate the conditions under which territories fall into a 'catch 22 ' loop characterized by unattractive industry dynamics for knowledge-intensive services businesses which threaten the sustainability of new manufacturing businesses. Future research on this topic should identify how specific policies seeking to revitalize manufacturing 
activities in territories with relatively undeveloped manufacturing industries-e.g., development of physical or digital infrastructures - align the interests of managers of manufacturing firms with those of new investors in knowledge-based service sectors if the virtuous circle is to work. Finally, and in line with our previous comment, differences in territorial development and in regulatory frameworks may affect the mediating role of industry characteristics on the consolidation of KIBS and manufacturing sectors across countries. The geographic specificity of the study calls for obvious caution when interpreting and generalizing its findings.

Acknowledgements: For their ideas and insights that helped us to improve the paper we are grateful to seminar participants at Birmingham Business School (Global Value Chain Seminar), Aston University (Servitization Conference 2015), and at the Universidad Rey Juan Carlos (4th International Conference on Business Servitization 2015). The authors are also thankful to Glenn Parry (UWE), Tommaso Aquilante (University of Birmingham) and the four anonymous referees for their insightful comments. Yancy Vaillant received financial support from the ESC Rennes School of Business. Esteban Lafuente acknowledges financial support from the Spanish Ministry of Science and Innovation (Grant: ECO2013-48496-C4-4-R). Ferran Vendrell-Herrero received financial support from the Spanish Ministry of Science and Innovation (Grant: ECO2014-58472-R) and from the European Union (Horizon 2020 Marie Skłodowska-Curie Actions Project MAKERS: Smart Manufacturing for EU Growth and Prosperity - Grant: 691192).

\section{References}

Acs, Z.J., Armington, C., Zhang, T., 2007. The determinants of new-firm survival across regional economies: The role of human capital stock and knowledge spillover. Papers in Regional Science, 86 (3), 367-391.

Acs, Z.J., Audretsch, D.B., 1988. Innovation in large and small firms: An empirical analysis. American Economic Review, 78 (4), 678-690. 
Acs, Z.J., Varga, A., 2004. Entrepreneurship, agglomeration and technological change. Paper presented at the first GEM Research Conference, 1-3 April 2004, Berlin.

Aldrich, H., Auster, E.R., 1986. Even dwarfs started small: Liabilities of Age and Size and their Strategic Implications. Research in Organizational Behavior, 8, 165-198.

Andersson, M., Lööf, H., 2011. Agglomeration and productivity: evidence from firm-level data. Annals of Regional Science, 46, 601-620.

Angrist, J., 2014. The Perils of Peer Effects. Labour Economics, 30, 98-108.

Arauzo, J.M., 2005. Determinants of industrial location: an application for Catalan municipalities. Papers in Regional Science, 84 (1), 105-120.

Armington, C., Acs, Z.J., 2002. The Determinants of Regional Variation in New Firm Formation. Regional Studies, 36 (1), 33-45.

Arnold, J.M., Javorcik, B., Lipscomb, M., Mattoo, A., 2016. Services Reform and Manufacturing Performance: Evidence from India. The Economic Journal, 126 (590), 1-39.

Baines, T., Shi, V.G., 2015. A Delphi study to explore the adoption of servitization in UK companies. Production Planning \& Control, 26 (14-15), 1171-1187.

Baines, T., Lightfoot, H., 2014. Servitization of the manufacturing firm: Exploring the operations practices and technologies that deliver advanced services. International Journal of Operations \& Production Management, 34 (1), 2-35.

Baines, T., Bigdeli, A., Bustinza, O.F., Shi, V., Baldwin, J., Ridgway, K., 2016. Servitization: Revisiting the state-of-the-art and research priorities. International Journal of Operations \& Production Management, in press.

Barnett, N.J., Parry, G., Saad, M., Newnes, L.B., Goh, Y.M., 2013. Servitization: is a paradigm shift in the business model and service enterprise required? Strategic Change, 22 (3-4), 145156.

Baron, R., Kenny, D., 1986. The moderator-mediator variable distinction in social psychological research: conceptual, strategic and statistical considerations. Journal of Personality and Social Psychology, 51, 1173-1182. 
Becattini, G., 1990. The Marshallian Industrial District as a Socio-economic Concept. in Pyke F., Becattini G., Sengenberger W. (eds), Industrial districts and interfirm cooperation in Italy, IILS, Geneva, p.38.

Bellandi, M., Sforzi, F., 2004. The Multiple Paths of Local Development. In G. Becattini, M. Bellandi, G. Dei Ottati and F. Sforzi (Eds.), From Industrial Districts to Local Development (pp. 210-226). Cheltenham: Edward Elgar.

Boix, R., Vaillant, Y., 2011. Industrial districts in rural areas of Italy and Spain. Sviluppo Locale, 14, 73-113

Bourlès, R., Cette, G., Lopez, J., Mairesse, J., Nicoletti, G., 2013. Do product market regulations in upstream sectors curb productivity growth? Panel data evidence for OECD countries. Review of Economics and Statistics, 95 (5), 1750-1768.

Bowen, D., Siehl, C., Schneider, B., 1989. A framework for analyzing customer service orientations in manufacturing. Academy of Management Review, 14, 75-95.

Cook, M.B., Bhamra, T.A., Lemon, M., 2006. The transfer and application of product service systems: from academia to UK manufacturing firms. Journal of Cleaner Production, 14, $1455-1465$.

Crozet, M., Milet E., 2015. Should everybody be in services? The effect of servitization on manufacturing firm performance. CEPII Working paper 2015-19.

Cusumano, M.A., Kahl, S.J., Suarez, F.F., 2015. Services, industry evolution, and the competitive strategies of product firms. Strategic Management Journal, 36 (4) 559-575.

Czarnitzki, D., Spielkamp, A., 2003. Business services in Germany: bridges for innovation. Service Industries Journal, 23 (2), 1-30.

Doloreux, D., Shearmur, R., 2013. Innovation Strategies: Are Knowledge-Intensive Business Services Just Another Source of Information? Industry and Innovation, 20 (8), 719-738.

Eriksson, R.H., Hansen, H.K., Lindgren, U., 2014. The importance of business climate and people climate on regional performance. Regional Studies, 48 (6), 1135-1155.

Europe INNOVA, 2009. Priority Sector Report: Knowledge Intensive Business Services.

Stockholm: Center for Strategy and Competitiveness. 
European Commission, 2007. Towards a European strategy in support of innovation in services:

Challenges and key issues for future actions, Commission Staff Working Document, SEC

1059. Brussels: Commission of the European Communities.

European Commission, 2011. Meeting the challenge of Europe 2020: The transformative power of service innovation. Report on the expert panel on service innovation in the EU. Luxembourg: Publications Office of the European Union.

European Commission, 2012. Knowledge-intensive (business) services in Europe. Luxembourg: Publications Office of the European Union (doi: 10.2777/59168).

Gebauer, H., Fleisch, E., 2007. An Investigation of the Relationship between Behavioral Processes, Motivation, Investments in the Service Business and Service Revenue. Industrial Marketing Management, 36, 337-348.

Grönroos, C., Voima, P., 2013. Critical service logic: Making sense of value creation and cocreation. Journal of the Academy of Marketing Science, 41 (2), 133-150.

Gunasekaran, A., Ngai, E.W., 2012. The future of operations management: an outlook and analysis. International Journal of Production Economics, 135 (2), 687-701.

Jacobs, W., Van Rietbergen, T., Atzema, O., Van Grunsven, L., Van Dongen, F., 2016. The impact of multinational enterprises (MNEs) on knowledge-intensive business services (KIBS) start-ups: empirical evidence from the Dutch Randstad. Regional Studies, 50 (4), 728-743.

Kohtamäki, M., Partanen, J., 2016. Co-creating value from knowledge-intensive business services in manufacturing firms: The moderating role of relationship learning in suppliercustomer interactions. Journal of Business Research, 69 (7), 2498-2506.

Lafuente, E., Vaillant, Y., Serarols, C., 2010. Location decisions of knowledge-based entrepreneurs: Why some Catalan KISAs choose to be rural? Technovation, 30, 590-600.

Lee, S., Yoo, S., Kim, D., 2016. When is servitization a profitable competitive strategy? International Journal of Production Economics, 173, 43-53. 
Leydesdorff, L., Dolfsma, W., Van der Panne, G., 2006. Measuring the knowledge base of an economy in terms of triple-helix relations among 'technology, organization, and territory'. Research Policy, 35 (2), 181-199.

Macneill, S., Jeannerat, H., 2016. Beyond production and standards: toward a status market approach to territorial innovation and knowledge policy. Regional Studies, 50 (2), 245-259.

Marshall, A., 1890. The principles of economics. London: McMillan.

Matthyssens, P., Vandenbempt, K., 2008. Moving from basic offerings to value-added solutions: Strategies, barriers and alignment. Industrial Marketing Management, 37 (3), 316328.

Muller, E., Zenker, A., 2001. Business services as actors of knowledge transformation: the role of KIBS in regional and national innovation systems. Research Policy, 30, 1501-1516.

Mueller, P., Van Stel, A., Storey, D.J., 2008. The effects of new firm formation on regional development over time: the case of Great Britain. Small Business Economics, 30, 59-71.

Munnell, A.H., 1992. Policy infrastructure investment and economic growth. Journal of Economic Perspectives, 6 (4), 189-198.

Neely, A., 2008. Exploring the financial consequences of the servitization of manufacturing. Operations Management Research, 1 (2), 103-118.

OECD, 2006. Innovation and Knowledge-Intensive Service Activities. OECD, Paris.

Oliva, R., Kallenberg, R., 2003. Managing the transition from products to services. International Journal of Service Industry Management, 14 (2), 160-172.

Opresnik, D., Taisch, M., 2015. The value of big data in servitization. International Journal of Production Economics, 165, 174-184.

Parry, G., Bustinza, O.F., Vendrell-Herrero, F., 2012. Servitisation and value co-production in the UK music industry: an empirical study of consumer attitudes. International Journal of Production Economics, 135 (1), 320-332.

Rabetino, R., Kohtamäki, M., Lehtonen, H., Kostama, H., 2015. Developing the concept of lifecycle service offering. Industrial Marketing Management, 49, 53-66. 
Reynolds, P., Bosma, N., Autio, E., Hunt, S., De Bono, N., Servais, I., Lopez, P., Chin, N., 2005. Global Entrepreneurship Monitor: Data collection design and implementation 19982003. Small Business Economics, 24, 205-231.

Reynolds P., Storey D., Westhead P., 2007. Cross-national Comparisons of the Variation in New Firm Formation Rates. Regional Studies, 28 (1), S123-S136.

Rocha, H., Sternberg, R., 2005. Entrepreneurship: the role of clusters, theoretical perspectives and empirical evidence from Germany. Small Business Economics, 24, 267-292.

Shearmur, R., Doloreux, D., 2015. Knowledge-Intensive Business Services (KIBS) Use and User Innovation: High-Order Services, Geographic Hierarchies and Internet Use in Quebec's Manufacturing Sector. Regional Studies, 49 (10), 1654-1671.

Smith, L., Maull, R., Ng, I., 2014. Servitization and operations management: A service dominant-logic approach. International Journal of Operations and Production Management, 34 (2), 242-269.

Sternberg, R., Arndt, O., 2001. The firm or the region: what determines the innovation behaviour of European firms? Economic Geography, 7, 364-382.

Strambach, S., 2001. Innovation processes and the role of Knowledge Intensive Business Services (KIBS). In K. Koschartzy, M. Kulicke and A. Zenker (Eds.), Innovation Networks, 12: Physical - Verlag HD (pp. 53-68).

Suarez, F.F., Cusumano, M.A., Kahl, S., 2013. Services and the business models of product firms: an empirical analysis of the software industry. Management Science, 59 (2), 420-435.

Surroca, J., Tribó, J., Waddock, S., 2010. Corporate Responsibility and Financial Performance: The Role of Intangible Resources. Strategic Management Journal, 31, 463-490.

Teece, D.J., 1980. Economies of scope and the scope of the enterprise. Journal of Economic Behavior \& Organization, 1, 223-247.

Teece, D.J., 2010. Business models, business strategy and innovation. Long Range Planning, 43 (2-3), 172-194. 
Vaillant, Y., Lafuente, E., Serarols, C., 2012. Location decisions of new 'Knowledge Intensive Service Activity' firms: the rural-urban divide. The Service Industries Journal, 32 (16), 2543-2563.

Vandermerwe, S., Rada, J., 1989. Servitization of business: adding value by adding services. European Management Journal, 6 (4), 314-324.

Vendrell-Herrero, F., Wilson, J., 2016. Servitization for territorial competitiveness: Taxonomy and research agenda. Competitiveness Review, in press (doi: 10.1108/CR-02-2016-0005)

Vendrell-Herrero, F., Bustinza, O.F., Parry, G., Georgantzis, N., 2016. Servitization, digitization and supply chain interdependency. Industrial Marketing Management., in press (doi: 10.1016/j.indmarman.2016.06.013).

Visnjic, I., Van Looy, B., 2013. Servitization: disentangling the impact of service business model innovation on manufacturing firm performance. Journal of Operations Management, $31,169-180$.

Visnjic, I., Wiengarten, F., Neely, A., 2016. Only the brave: Product innovation, service business model innovation, and their impact to performance. Journal of Product Innovation Management, 33 (1), 36-52.

Wise, R., Baumgartner, P., 1999. Go downstream: The new profit imperative in manufacturing. Harvard Business Review, 77 (5), 133-141.

Wooldridge, J.M., 2008. Econometric Analysis of Cross Section and Panel Data. Second edition, Cambridge, Massachusetts: The MIT Press.

Zhen, L., 2012. An analytical study on service-oriented manufacturing strategies. International Journal of Production Economics, 139 (1), 220-228. 


\section{List of Figures}

Figure 1. Conceptual framework

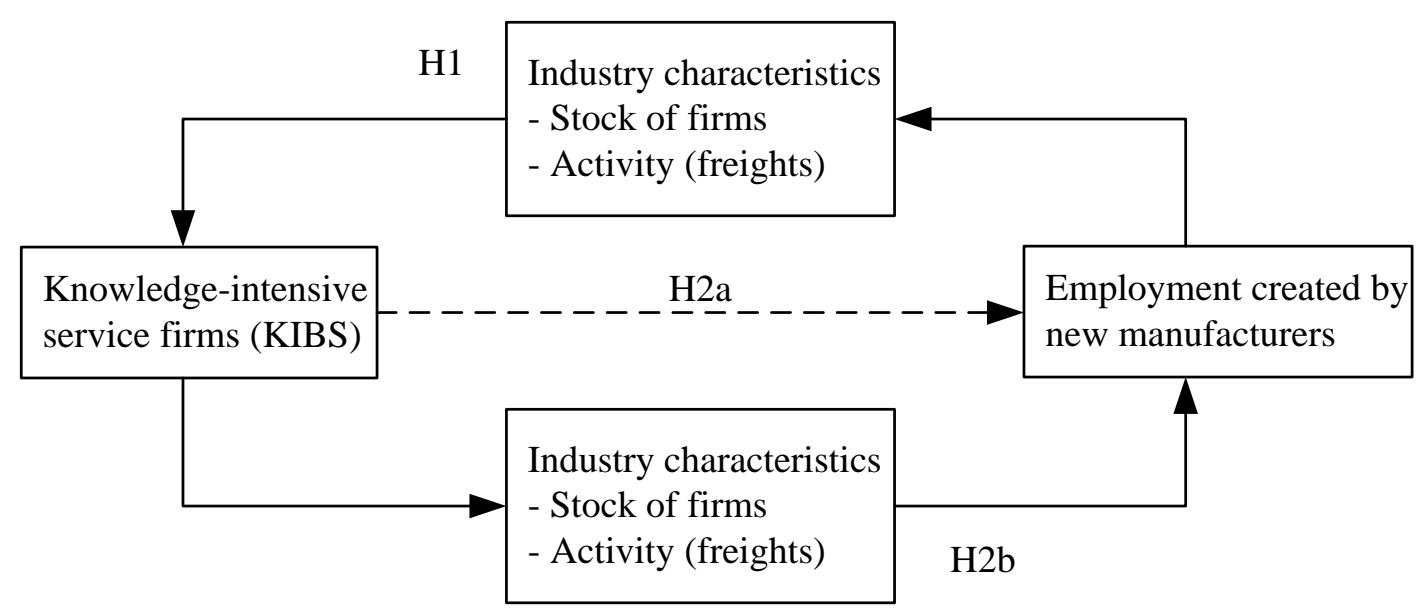

Source: Authors' elaboration.

Figure 2. Employment created by new manufacturing firms distinguishing territories with high (above-the-median) and low (below-the-median) KIBS firms start-up rates

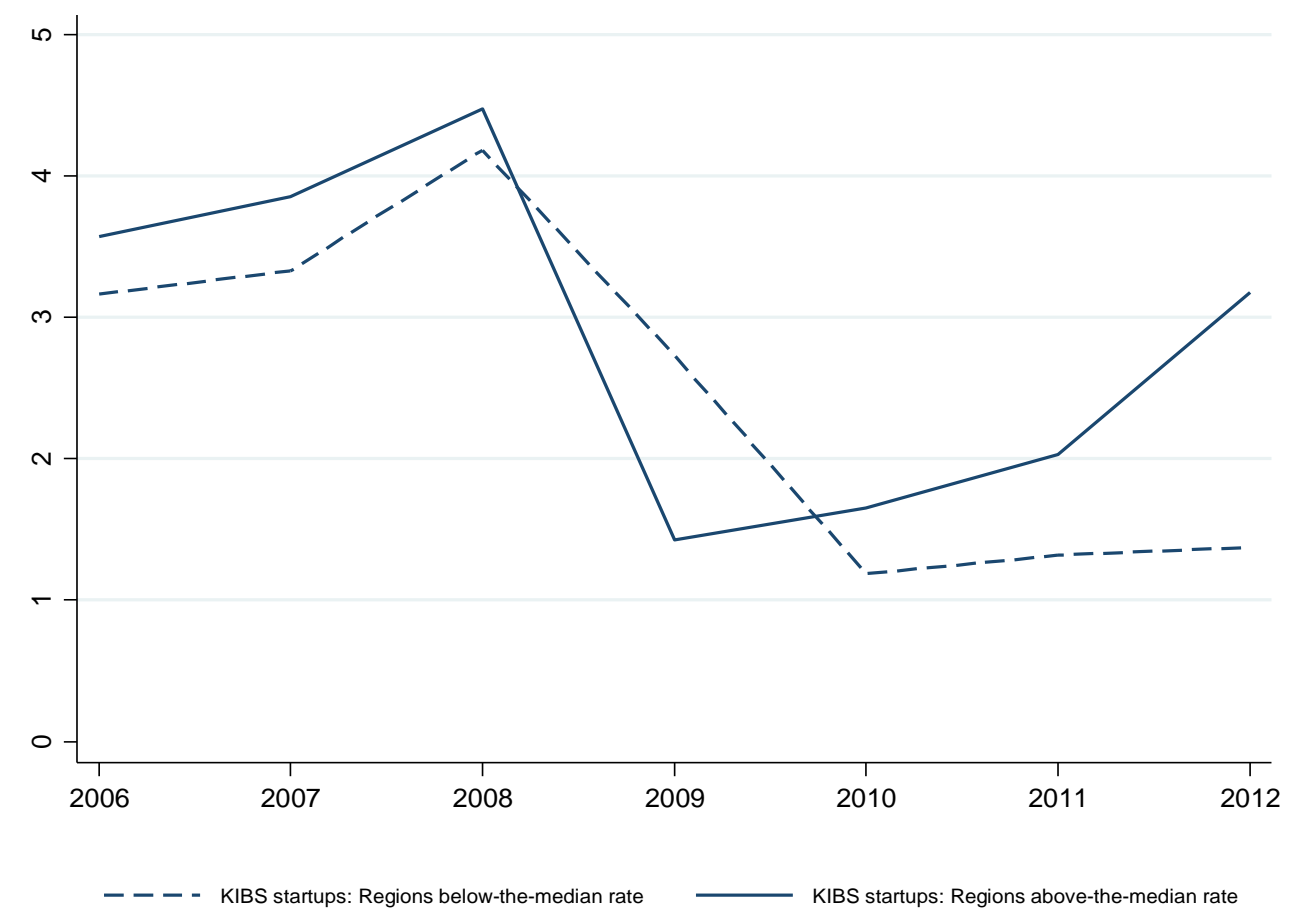

Source: Authors' elaboration on Global Entrepreneurship Monitor (GEM) data. 


\section{List of Tables}

Table 1. Descriptive statistics for the selected variables

\begin{tabular}{|l|c|c|c|c|}
\hline Variable & Mean & Std. dev. & Minimum & Maximum \\
\hline Rate of KIBS business formation (in \%) & 19.51 & 26.22 & 0.0000 & 70.81 \\
\hline $\begin{array}{l}\text { Employment of new manufacturing } \\
\text { firms (employees) }\end{array}$ & 3.06 & 2.25 & 0.00 & 14.29 \\
\hline Stock of manufacturing firms & $12,718.39$ & $11,497.44$ & $2,062.00$ & $48,436.00$ \\
\hline $\begin{array}{l}\text { Total air and maritime transport of } \\
\text { freights (in thousands of tons) }\end{array}$ & $23,231.37$ & $29,499.04$ & 0.0000 & $119,595.00$ \\
\hline Unemployment rate (in \%) & 14.94 & 7.24 & 4.70 & 34.40 \\
\hline $\begin{array}{l}\text { GDP per head } \\
\text { (expressed in constant 2012 euro) }\end{array}$ & $24,096.99$ & $4,551.35$ & $15,700.00$ & $32,878.10$ \\
\hline
\end{tabular}

Sample size: 119 observations.

Table 2. Fixed effects regression results: Mediation effects

\begin{tabular}{|c|c|c|c|c|}
\hline & \multicolumn{2}{|c|}{ Rate of new KIBS firms } & \multicolumn{2}{|c|}{$\begin{array}{l}\text { Average employment creation } \\
\text { in manufacturing firms }\end{array}$} \\
\hline & (1) & (2) & (3) & (4) \\
\hline $\begin{array}{l}\text { Average employment in new } \\
\text { manufacturing firms }(t-1)\end{array}$ & $\begin{array}{c}0.0495 * * \\
(0.0214)\end{array}$ & & & \\
\hline $\begin{array}{l}\text { Instrument: Average employment } \\
\text { in new manufacturing firms }(t-1)\end{array}$ & & $\begin{array}{l}-0.0141 \\
(0.0238)\end{array}$ & & \\
\hline Rate of new KIBS firms $(t-l)$ & & & $\begin{array}{l}0.3613 * * \\
(0.1491) \\
\end{array}$ & \\
\hline $\begin{array}{l}\text { Instrument: Rate of new KIBS } \\
\text { firms }(t-1)\end{array}$ & & & & $\begin{array}{c}0.3969 \\
(0.3846)\end{array}$ \\
\hline Stock of manufacturing firms $(t-l)$ & & $\begin{array}{l}-0.1126 \\
(0.4255)\end{array}$ & & $\begin{array}{l}1.6773 * * \\
(0.8499)\end{array}$ \\
\hline $\begin{array}{l}\text { Freights transported (in thousands } \\
\text { of tons) }(t-1)\end{array}$ & & $\begin{array}{l}0.1913 * * * \\
(0.0321)\end{array}$ & & $\begin{array}{l}0.1825 * * \\
(0.0842)\end{array}$ \\
\hline Unemployment rate $(t-l)$ & $\begin{array}{c}-0.0164 * \\
(0.0109) \\
\end{array}$ & $\begin{array}{c}-0.0172^{*} \\
(0.0105)\end{array}$ & $\begin{array}{c}0.0894 * * * \\
(0.0340)\end{array}$ & $\begin{array}{c}0.0834 * * * \\
(0.0191) \\
\end{array}$ \\
\hline GDP per head $(t-l)$ & $\begin{array}{c}0.8777 \\
(1.1313) \\
\end{array}$ & $\begin{array}{c}0.6039 \\
(1.2119) \\
\end{array}$ & $\begin{array}{l}2.3028 * \\
(1.1958)\end{array}$ & $\begin{array}{l}2.5368^{*} \\
(1.5233) \\
\end{array}$ \\
\hline Time dummies & Yes & Yes & Yes & Yes \\
\hline Intercept & $\begin{array}{c}4.1711 \\
(6.5006) \\
\end{array}$ & $\begin{array}{c}4.7266 \\
(5.5688) \\
\end{array}$ & $\begin{array}{l}-5.0678 \\
(4.3868) \\
\end{array}$ & $\begin{array}{l}-3.4723 \\
(2.4508) \\
\end{array}$ \\
\hline R-square (within) & 0.5708 & 0.6081 & 0.2637 & 0.3248 \\
\hline F-test & $23.88 * * *$ & $57.28 * * *$ & $7.53 * * *$ & $9.90 * * *$ \\
\hline Average VIF & 2.69 & 3.10 & 2.61 & 6.14 \\
\hline Observations & 102 & 102 & 102 & 102 \\
\hline
\end{tabular}

Robust standard error is in brackets. *,**,*** indicate significance at the $10 \%, 5 \%$ and $1 \%$, respectively. 


\section{Appendix}

Table A1. Correlation matrix

\begin{tabular}{|c|c|c|c|c|c|c|}
\hline & 1 & 2 & 3 & 4 & 5 & 6 \\
\hline $\begin{array}{l}\text { 1. Rate of KIBS } \\
\text { business formation }\end{array}$ & 1 & & & & & \\
\hline $\begin{array}{l}\text { 2. Employment of new } \\
\text { manufacturing firms }\end{array}$ & $0.3416^{* * *}$ & 1 & & & & \\
\hline $\begin{array}{l}\text { 3. Stock of } \\
\text { manufacturing firms }\end{array}$ & $0.2106^{* *}$ & $0.1795^{* *}$ & 1 & & & \\
\hline $\begin{array}{l}\text { 4. Total air and } \\
\text { maritime transport of } \\
\text { freights (in thousands } \\
\text { of tons) }\end{array}$ & 0.0052 & 0.0882 & $0.1716^{* *}$ & 1 & & \\
\hline 5. Unemployment rate & $-0.4854 * * *$ & $-0.3245 * *$ & $-0.2489 * * *$ & 0.1254 & 1 & \\
\hline 6. GDP per head & $0.1682 *$ & $0.1083^{*}$ & $0.2437 * *$ & -0.0187 & $-0.5698 * * *$ & 1 \\
\hline
\end{tabular}

$*, * *, * * *$ indicate significance at the $10 \%, 5 \%$ and $1 \%$, respectively.

Table A2. Fixed effects regression results

\begin{tabular}{|c|c|c|c|c|}
\hline & \multicolumn{2}{|c|}{ Stock of manufacturing firms } & \multicolumn{2}{|c|}{$\begin{array}{l}\text { Freights transported } \\
\text { (in thousands of tons) }\end{array}$} \\
\hline & $(1)$ & $(2)$ & (3) & (4) \\
\hline Rate of new KIBS firms $(t-1)$ & $\begin{array}{c}0.0263 * * \\
(0.0131) \\
\end{array}$ & & $\begin{array}{c}0.3792 * * \\
(0.1891) \\
\end{array}$ & \\
\hline $\begin{array}{l}\text { Average employment } \\
\text { creation in manufacturing } \\
\text { firms }(t-1)\end{array}$ & & $\begin{array}{l}0.0087 * * \\
(0.0039)\end{array}$ & & $\begin{array}{l}0.0553 * \\
(0.0309)\end{array}$ \\
\hline Unemployment rate $(t-1)$ & $\begin{array}{c}0.0035 \\
(0.0042)\end{array}$ & $\begin{array}{c}0.0030 \\
(0.0043)\end{array}$ & $\begin{array}{l}-0.0047 \\
(0.0087)\end{array}$ & $\begin{array}{l}-0.0005 \\
(0.0099)\end{array}$ \\
\hline GDP per head $(t-1)$ & $\begin{array}{c}1.1932 * * * \\
(0.3106)\end{array}$ & $\begin{array}{c}1.1247 * * * \\
(0.3117)\end{array}$ & $\begin{array}{c}1.2200 \\
(0.9296)\end{array}$ & $\begin{array}{r}0.5987 \\
(1.0675) \\
\end{array}$ \\
\hline Time dummies & Yes & Yes & Yes & Yes \\
\hline Intercept & $\begin{array}{l}-3.3802 \\
(3.1800) \\
\end{array}$ & $\begin{array}{l}-2.6621 \\
(3.1916) \\
\end{array}$ & $\begin{array}{c}1.9033 \\
(1.9388) \\
\end{array}$ & $\begin{array}{c}2.2568 \\
(2.7752) \\
\end{array}$ \\
\hline R-square (within) & 0.8271 & 0.8199 & 0.3358 & 0.1109 \\
\hline F-test & $137.35 * * *$ & $100.75 * * *$ & $4.48 * * *$ & $3.67 * * *$ \\
\hline Average VIF & 2.77 & 2.69 & 2.77 & 2.69 \\
\hline Observations & 102 & 102 & 102 & 102 \\
\hline
\end{tabular}

Robust standard error is in brackets. *,**,*** indicate significance at the $10 \%, 5 \%$ and $1 \%$, respectively. 
Table A3. Fixed effects regression results: Robustness check

\begin{tabular}{|c|c|c|}
\hline & $\begin{array}{l}\text { Rate of new } \\
\text { KIBS firms }\end{array}$ & $\begin{array}{l}\text { Average employment in } \\
\text { new manufacturing firms }\end{array}$ \\
\hline $\begin{array}{l}\text { Average employment in new manufacturing } \\
\text { firms }(t-1)\end{array}$ & $\begin{array}{c}0.0198 * * \\
(0.0223)\end{array}$ & \\
\hline Rate of new KIBS firms $(t-1)$ & & $\begin{array}{c}0.4434 * * \\
(0.2123)\end{array}$ \\
\hline Stock of manufacturing firms $(t-1)$ & $\begin{array}{c}0.0235 \\
(0.3727)\end{array}$ & $\begin{array}{c}0.3618 \\
(1.8737)\end{array}$ \\
\hline Freights transported (in thousands of tons) $(t-1)$ & $\begin{array}{l}0.1505 * * \\
(0.0739)\end{array}$ & $\begin{array}{l}0.4681 * \\
(0.2818)\end{array}$ \\
\hline Unemployment rate $(t-1)$ & $\begin{array}{c}-0.0171 * * \\
(0.0063)\end{array}$ & $\begin{array}{l}0.0572 * \\
(0.0329) \\
\end{array}$ \\
\hline GDP per head $(t-l)$ & $\begin{array}{c}1.0420 \\
(0.9115)\end{array}$ & $\begin{array}{l}1.1717 * * \\
(0.5577)\end{array}$ \\
\hline Time dummies & Yes & Yes \\
\hline Intercept & $\begin{array}{c}1.1598 \\
(0.8025)\end{array}$ & $\begin{array}{c}6.5993 \\
(4.2852)\end{array}$ \\
\hline R-square (within) & 0.5898 & 0.2734 \\
\hline F-test & $39.82 * * *$ & $5.30 * * *$ \\
\hline Average VIF & 2.70 & 2.76 \\
\hline Observations & 102 & 102 \\
\hline
\end{tabular}

Robust standard error is in brackets. *,**,*** indicate significance at the $10 \%, 5 \%$ and $1 \%$, respectively. 